22 Sri Poeranto : Escalating Dose Antigen Specific Therapy with dsDNA Injection Regulate Balance Ratio

\title{
Escalating Dose Antigen Specific Therapy with dsDNA Injection Regulate Balance Ratio of Inflammatory Cells in Pristane-Induced Lupus Mice Model
}

\author{
S Poeranto', K Handono², N Nurdiana ${ }^{3}$, S Arifin ${ }^{4 *}$, K D Hartanti ${ }^{4}$, T M Albaar ${ }^{4}$, R \\ Gumilang $^{4}$, N A Dharmesta ${ }^{4}$ \\ ${ }^{1}$ Department of Clinical Parasitology, Faculty of Medicine Universitas Brawijaya, Indonesia \\ ${ }^{2}$ Department of Clinical Pathology, Faculty of Medicine Universitas Brawijaya, Indonesia \\ ${ }^{3}$ Department of Pharmacology, Faculty of Medicine Universitas Brawijaya, Indonesia \\ ${ }^{4}$ Master Degrees of Biomedical Sciences, Faculty of Medicine Universitas Brawijaya, \\ Indonesia \\ *Corresponding author: akulahperubahan24@gmail.com
}

\begin{abstract}
Immunosuppressant and steroid therapy for SLE have not shown satisfactory results. Another method of therapy that is being developed is vaccines and escalating dose immunotherapy using self-antigen. The aim of this study was to assess the balance of immune cells through the ratio of pro-inflammatory and anti-inflammatory cells and cytokines in SLE using self-antigen dsDNA therapy. Methods: Female Balb/c mice 6-8 weeks old separated randomly to negative control group and pristane induced lupus (PIL) mice group. PIL mice groups were injected pristane intraperitoneally. Twelve weeks after the injection, the mice were evaluated for clinical and serological manifestations (anti-dsDNA levels). Mice with lupus signs were divided into four groups; positive control group: PIL mice without EDI dsDNA therapy, treatment A: PIL mice with EDI dsDNA therapy dose I $(0.01 \mu \mathrm{g} / \mathrm{ml}, 0.1 \mu \mathrm{g} / \mathrm{ml}, 1 \mu \mathrm{g} / \mathrm{ml})$, treatment B: PIL mice with EDI dsDNA therapy dose II $(0.1 \mu \mathrm{g} / \mathrm{ml}, 1 \mu \mathrm{g} / \mathrm{ml}, 10 \mu \mathrm{g} / \mathrm{ml})$, and treatment C: PIL mice with EDI dsDNA therapy dose III $(1 \mu \mathrm{g} / \mathrm{ml}, 10 \mu \mathrm{g} / \mathrm{ml}, 100 \mu \mathrm{g} / \mathrm{ml})$. dsDNA were injected once a week and the dose was increased every week. Samples were analyzed for active/inactive dendritic cells ratio, Th1/Th2 cells ratio, Th17/Treg cells ratio and IL-17/TGF- $\beta$ levels ratio. Results: Escalating dose antigen specific therapy with dsDNA injection of third dose reduced active/inactive dendritic cells ratio $(\mathrm{p}=0.000)$, Th1/Th2 cells ratio $(\mathrm{p}=0.010)$, Th17/Treg ratio $(\mathrm{p}=0.004)$ and decrease IL-17/TGF- $\beta$ levels ratio $(\mathrm{p}=0.004)$ significantly compared to positive control. Conclusion: Escalating dose antigen specific therapy with dsDNA injection of dose III was able to regulate balance ratio of inflammatory cells and cytokines in PIL mice thus the immune tolerance may improve compared to control groups.
\end{abstract}

Keywords: systemic lupus erythematosus, dsDNA, escalating dose, tolerance

\section{INTRODUCTION}

Systemic Lupus Erythematosus (SLE) is a chronic autoimmune disease characterized by hyperactive immune responses and the production of abnormal autoantibodies that eventually cause tissue and organ damage (Zhu and Mohan, 2007; Sawla et al., 2012). The World Health Organization or WHO records the number of people with lupus in the world today 
about five million people. In Indonesia, the trend of lupus disease in hospitalized patients has increased since 2014-2016 (Pusdatin Kemenkes, 2017).

SLE is characterized by a loss of globally immune tolerance with activation of autoreactive T cells and B cells that lead to the production of pathogenic autoantibodies and tissue damage (Choi et al., 2012). The presence of abnormalities of the immune system is caused by a disturbance in T-regulator cell function (Treg) in regulating the immune response and this affects the hyper activation of various helper T cells (Th). Dendritic cells can recognize different types of self-antigen, especially dsDNA which has an important role in the pathogenesis of SLE, and through activation of B cells will stimulate the formation of antibodies against self-antigen dsDNA (Pathak and Mohan, 2011). Many autoimmune diseases produce autoantibody production, but anti-dsDNA antibodies are very specific for SLE disease. Recent studies have shown 100\% anti-dsDNA specificity in healthy patients and $97 \%$ in patients with multiple health problems (Wichainun et al., 2013).

Current SLE therapies include immunosuppressant and steroid drugs that have not shown satisfactory results yet. The use of steroid drugs that should be consumed longterm also still cause many side effects in people with SLE (Pathak and Mohan, 2011). Therefore, it is still necessary to develop SLE therapy in inducing and improving the regulation of the immune system against autoantigen so as to improve the clinical condition of SLE patient's maximally (Handono et al., 2013).
A recent study has found a method of immunological therapy in allergic and autoimmune diseases, namely Escalating Dose (Antigen-Specific) Immunotherapy (EDI). EDI is a therapeutic method for suppressing the immune response through a tolerance mechanism by injecting an autoantigen (selfantigen) that stimulates the formation of autoantibodies with a gradual dose to elicit a desensitization effect. Gradual and increased dosing is done to avoid adverse effects from the mild to the most severe, anaphylactic shock (Larché and Wraith, 2005).

T-reg cells have an important role in the development of tolerance therapy with specific antigen. Induction of IL10 cytokines as immunomodulatory demonstrates the effectiveness of immunotherapy in both mice and humans (Tarzi et al., 2006; Campbell et al., 2009; Fousteri et al., 2010). During the immunotherapy process, chronic stimulation of CD4 cells with antigen peptide administration alters the transcriptional program (Anderson et al., 2006) so that pathogenic $\mathrm{T}$ cells are transformed into anergy, IL10 secretion, cell with regulatory phenotype capable of preventing autoimmunity (Gabrysova et al., 2009).

Recent research 14 proves the safety of immunotherapy using specific antigen with EDI method. The study was conducted on an autoimmune encephalomyelitis model from multiple sclerosis with therapy using myelin basic protein. The study proves that excessive activation of CD4 $\mathrm{T}$ cells can be avoided by providing a low dose of immunotherapy first. Using the EDI protocol, the administration of a specific antigen achieves the highest dose 
required to induce IL10 without increasing other inflammatory cytokines. Therapy with this method shows the effects of cell anergy, cell suppression, and increased expression of IL10 (Burton et al., 2014).

Based on the success of that study, researchers wanted to know the effect of administering self antigen dsDNA with EDI method as immunotherapy in SLE autoimmune disease. Research on the method of EDI self antigen dsDNA in lupus today has never been done. The purpose of this study is to explore the use of self antigen dsDNA with EDI method in

\section{METHODS}

Mice

Female Balb/c mice that were $6-8$-weeks-old and 20-30 grams body weight were obtained from Veterinarian Center (Malang, Indonesia). All mice were housed at Pharmacology Laboratory, Faculty of Medicine Universitas Brawijaya, given for water and food ad libitum. Isolation dsDNA and Preparation

The ds-DNA antigen was isolated from the blood of healthy mice. The DNA isolation was carried out using the materials and procedures of NucleoSpin®. The results of DNA isolation were then measured in concentration using nanodrop. dsDNA were mixed with PEI (N/P = 6), $10 \%$ glucose, and sterile aquades until it reaches the injection volume. The Injection volume was $500 \mu \mathrm{l}$. We used the ratio of $\mathrm{N} / \mathrm{P}$ (DNA/ polyethylenimine) of 6 or in other words $0.12 \mu \mathrm{l}$ PEI per $\mu$ g nucleic acid/DNA. dsDNA is mixed with $10 \%$ glucose, PEI, and sterile aquades and then vortex slowly and spin down. The solution was incubated for 15 minutes at room temperature for the complex to stabilize. restoring the balance of inflammatory cells in SLE disease including the ratio of active/inactive dendritic cells, Th1/Th2, Th17/Treg cells, and levels of IL-17/TGF- $\beta$ cytokines. This is because the decrease in the ratio of active/inactive dendritic cells shows decreased activity of dendritic cells (Singh et al., 2013; Plantinga et al., 2011) and imbalances of Th1/Th2, Th17/Treg, and levels of IL$17 /$ TGF- $\beta$ correlates with the severity of SLE disease (Ma et al., 2010; Dolff et al., 2011; Guimaraes et al., 2017)

The solution was injected intraperitoneally according to the dose of each treatment group (Huang et al., 2012).

Induction and treatment of pristane-induced lupus mice model

$\mathrm{Balb} / \mathrm{c}$ female mice 6-8 weeks old were separated randomly to negative control group (healthy mice) and pristane induced lupus (PIL) mice group. PIL mice groups were injected 0.5 cc $(782 \mu \mathrm{g} / \mathrm{ml})$ pristane intraperitoneally. Twelve weeks after the injection of pristane, the mice were evaluated for clinical and serological manifestations (anti-dsDNA levels). Mice with lupus signs or PIL mice were divided into four groups; positive control group: PIL mice without EDI dsDNA therapy, treatment A: PIL mice with EDI dsDNA therapy dose I (0.01 $\mu \mathrm{g} / \mathrm{ml}, 0.1 \mu \mathrm{g} / \mathrm{ml}, 1 \mu \mathrm{g} / \mathrm{ml}$ ) were administered once a week consecutively, treatment B: PIL mice with EDI dsDNA therapy dose dose II ( 0.1 $\mu \mathrm{g} / \mathrm{ml}, 1 \mu \mathrm{g} / \mathrm{ml}, 10 \mu \mathrm{g} / \mathrm{ml}$ ) were administered once a week consecutively and treatment $\mathrm{C}$ : PIL mice with EDI dsDNA therapy dose III (1 
$\mu \mathrm{g} / \mathrm{ml}, 10 \mu \mathrm{g} / \mathrm{ml}, 100 \mu \mathrm{g} / \mathrm{ml}$ ) were administered once every week in consecutively.

Cell preparation

Preparation from spleen tissue was done using previous protocol methods. Spleen tissues were harvested and teased apart into suspension by pressing them with the plunger. Tissues were collected in $10 \mathrm{ml}$ of staining buffer and passed cell suspension through a cell strainer to eliminate clumps and debris, then collected cell suspension in a conical tube. The cell suspension was centrifuged for 4-5 $\min (300$ $400 \mathrm{x}$ g) at $4^{\circ} \mathrm{C}$ and the supernatant was removed. Red blood cell lysis was performed. Samples were resuspended in $50 \mathrm{ml}$ of staining buffer.

Flowcytometry analysis

Cells that had been taken from spleen were stained using antibody markers to assess CD4+ T cells subsets percentages, including Th1, Th2, and Th17, and Treg by flow cytometry. Cells were labeled with FITC antimouse CD4. Before intracellular staining, cells were stimulated with phorbolmyristate acetate $(50 \mathrm{ng} / \mathrm{ml})$ and ionomycin $(1 \mu \mathrm{g} / \mathrm{ml})$ in the presence of Brefeldin A for at least $4 \mathrm{~h}$. Intracellular staining was performed using PerCP antimouse IFN- $\gamma$ to detect Th1 cells, PE antimouse IL-4 to detect Th2 cells, PE antimouse IL-17A to detect Th17 cells. For the detection of Treg, cells were labeled with FITC antimouse CD4, PerCP antimouse CD25, and PE antimouse FoxP3. Active dendritic cells were stained using antimouse CD45-PE and CD11b-FITC which has been diluted with CSB with a certain ratio. Inactive dendritic cells were stained using anti- mouse CD11c-FITC. The solution then incubated for 20 minutes at room temperature in dark place. Staining was performed according to Biolegend manufacture protocols. All cells were analyzed using Cellquestpro software.

Proinflammatory cytokines and autoantibody assay

Whole blood samples of the mice were collected from their heart following the euthanasia procedure with ketamin injection. The blood samples were allowed to clot by leaving it at room temperature for 15-30 min, and the clot was removed by centrifuging it at 1000-2000 × g for $10 \mathrm{~min}$. Interleukin-17 (IL17) and transforming growth factor beta (TGF$\beta)$ levels from serum were determined using enzyme-linked immunosorbent assay (ELISA) kits. Antibody anti-dsDNA from serum was also determined using ELISA kit.

Data Collection and Analysis Procedures.

The results of measured parameters were analyzed statistically by using the IBM SPSS Statistics 22 program with a significance level of $0.05(p=0.05)$ and confidence level of $95 \%$ $(\alpha=0.05)$. The steps of hypotetic comparative and correlative testing are normality test, variance homogeneity test, One-Way ANOVA test, and Post hoc test.

Ethiccal Aproval

All experimental protocols described in this study were approved by the Ethical Committee for Animal Experimentation of Faculty of Medicine Universitas Brawijaya (No. 336/EC/KPEK/09/2016). 


\section{RESULT}

Serum levels of dsDNA autoantibodies were measured to see the ability of EDI dsDNA to inhibit the production of anti-dsDNA. AntidsDNA levels were higher in the positive control group $(68.27 \mathrm{ng} / \mathrm{ml})$ compared with the negative control group (17.2 ng/ml) (Figure 1a). The treatment group had lower levels (20.72 $\mathrm{ng} / \mathrm{ml}$ ) but did not differ significantly compared with the positive control group.

Number of dendritic cells measured from the spleen tissue using flowcytometry method. The active dendritic cells are cells with CD45+

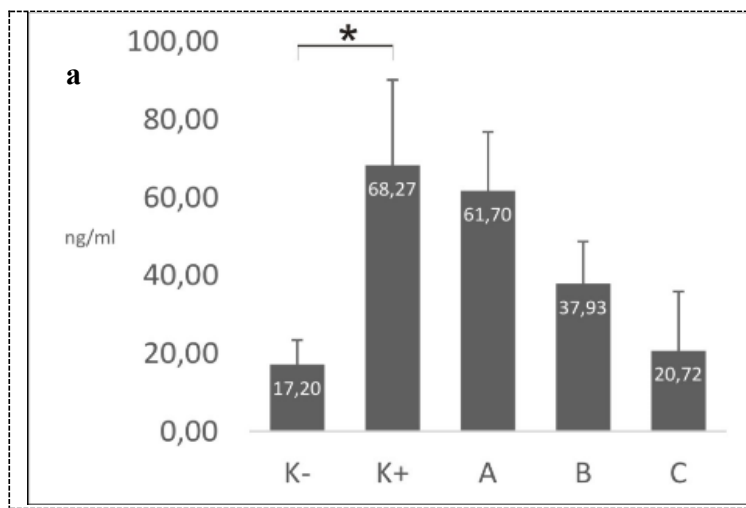

Figure 1. Comparison of dsDNA levels between Groups

The Th1/Th2 ratios were measured by dividing the percentage of Th1 cells by the percentage of Th2 cells. The Th1/Th2 ratio in the positive group (1.21\%) increased significantly $(\mathrm{p}=0.008)$ compared with the negative group $(0.71 \%)$ (Figure 2a). The Th1/Th2 ratio in the treatment group decreased when compared with the positive group with the lowest value being in group C $(0.73 \%)$ ( $\mathrm{p}$ $=0.010)$.

The Th17/Treg ratios were measured by dividing the percentage of Th17 cell by the percentage of Treg cell count. The Th17/Treg ratio in the positive group $(0.42 \%)$ increased
CD11b+ markers. Inactive dendritic cells are cells with $\mathrm{CD} 11 \mathrm{c}+$ markers. The ratio of active and passive dendritic cells was measured by dividing the number of active dendritic cells with inactive dendritic cells (Figure 1b). The ratio of active/inactive cells in the positive group (1.29\%) increased significantly (p $=0.000)$ compared with the negative group $(0.30 \%)$. This ratio decreased significantly in the treatment groups A $(\mathrm{p}=0.002), \mathrm{B}(\mathrm{p}=0.001)$ and $\mathrm{C}(\mathrm{p}=0.000)$.

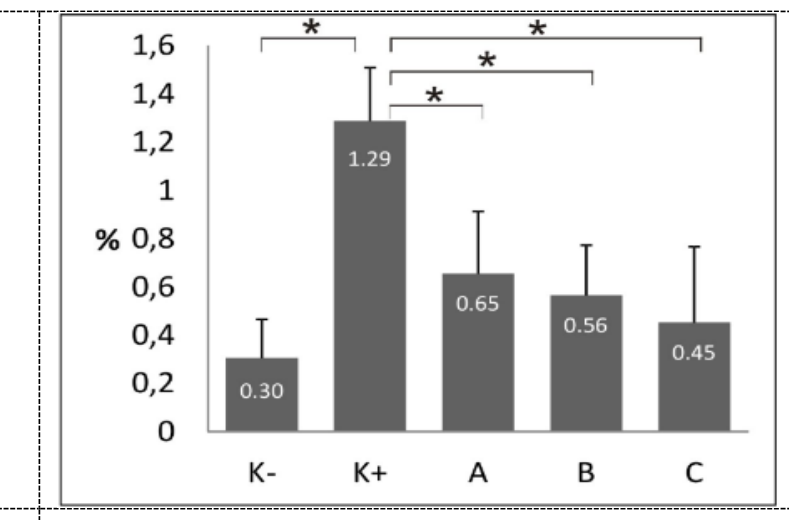

Figure 2. Comparison of Active/Inactive Dendritic Cell Ratio between Groups

significantly ( $\mathrm{p}=0.019$ ) when compared with the negative group $(0.24 \%)$ (Figure $2 b)$. The Th17/Treg ratio in the treatment group tended to decrease significantly, especially in group $\mathrm{C}$ when compared with the positive group ( $p$ $=0.004)$.

The Th17/Treg ratio was also measured by the results of the cytokine profiles of IL-17 and TGF- $\beta$. The IL- $17 /$ TGF- $\beta$ ratio was calculated by dividing IL-17 levels by TGF- $\beta$ levels. The IL-17/TGF- $\beta$ ratio not significantly increased ( $p$ $=0.420)$ in the positive control group $(0.11)$ when compared with the negative control (0.09) (Figure $2 c$ ). The IL-17/TGF- $\beta$ ratio decreased 
significantly in the treatment group A $(p$ $=0.003), \mathrm{B}(\mathrm{p}=0.004)$ and $\mathrm{C}(\mathrm{p}=0.004)$ when compared with the positive group.

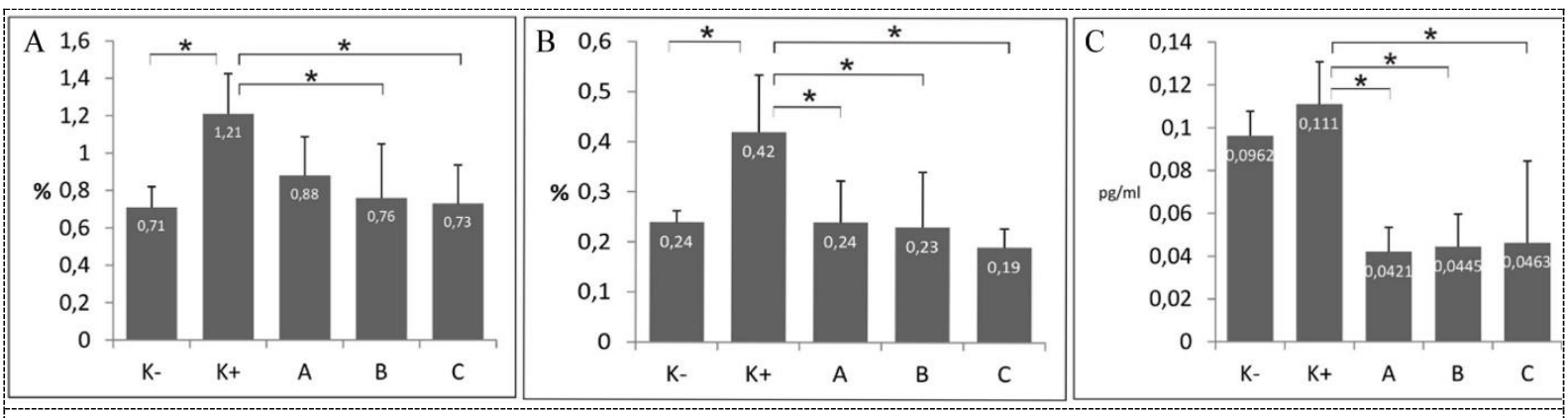

Figure 3. Comparison of Ratio (a) Number of Th1/Th2 Cells; (b) Number of Th17/Treg Cells; (c) IL-17/TGF- $\beta$

\section{DISCUSSION}

The presence of immune system abnormalities is due to disruption of Treg cell function in regulating the immune response and this affects the hyper activation of various helper T cells (Th). Th cells such as Th1, Th2, and Th17 will be activated by dendritic cells and other APC cells and stimulate the occurrence of inflammatory responses, macrophage cell activation, and activation of B cell lymphocytes. Dendritic cells can recognize different types of self antigens, especially dsDNA that have an important role in the pathogenesis of SLE, and through activation of $B$ cells will stimulate the formation of antibodies against dsDNA self antigen. The presence of these pathogenic autoantibodies will result in tissue damage due to immune complex deposition (Pathak and Mohan, 2011).

Increased dendritic cell activity in SLE plays an important role in the loss of immune tolerance in SLE. In this study increased dendritic cell activity is characterized by an increase in the ratio of active/inactive dendritic cells. Active dendritic cells are characterized by expression of $\mathrm{CD} 11 \mathrm{~b}$ on the cell surface
(Plantinga et al., 2011) while inactive dendritic cells are characterized by CD11c expression on the cell surface (Singh et al., 2013). Results showed an increase in the ratio of active/inactive dendritic cells significantly in PIL mice compared with normal mice. It shows an increase in dendritic cell activity in PIL mice. EDI administration of dsDNA showed a significantly decreased ratio of dendritic active/inactive cells with the best dose shown at the third dose $(1 \mu \mathrm{g} / \mathrm{ml}, 10 \mu \mathrm{g} / \mathrm{ml}, 100 \mu \mathrm{g} / \mathrm{ml})$. This suggests EDI dsDNA can suppress dendritic cell activity.

Treg cells are a subpopulation of CD4 $+\mathrm{T}$ lymphocyte cells that play a role in inhibiting immune cell activity, inducing immune tolerance that may inhibit the autoimmune process. These Treg cells can be identified in peripheral blood through a variety of surface markers, including CD4 $+\mathrm{CD} 25+$ and intracellular forkhead box marker P3 (FoxP3) (Elias et al., 2008). Treg cells have a suppressive function against the inflammatory response by producing TGF- $\beta$ and IL-10 cytokines. Both of these cytokines have been 
shown to suppress the activity of other immune cells (Afzali et al., 2007). Previous research has also proven that Treg cells can play a direct role in inhibiting the activity of Th1, Th2, Th17, and cell B cells (Elias et al., 2008).

Activation of Treg cells is also mediated by the TGF- $\beta$ cytokine. TGF- $\beta$ may bind to TGF- $\beta$ receptors in naive $\mathrm{T}$ cells so that the STAT5 transcription factor is activated. The phosphorylation of STAT5 results in activation of the FoxP3 transcription factor which is a marker of T-reg cell differentiation. Active Treg cells will express cell markers such as CD4 $+\mathrm{CD} 25+$ FoxP $3+$ and may produce TGF- $\beta$ and IL-10 cytokines (Elias et al., 2008).

In chronic inflammatory conditions such as SLE, elevated levels of IL-6 cytokines arise due to activation of various immune cells, such as macrophages and $\mathrm{T}$ cells. This cytokine production can inhibit the activation of FoxP3 so that T-reg cell differentiation processes can also be inhibited. TGF- $\beta$ working together with IL-6 will activate STAT3 which induces the formation of retinoid-associated orphan receptor $\gamma \mathrm{t}(\mathrm{ROR} \gamma \mathrm{t})$ and $\mathrm{ROR} \alpha$ transcription factors (Kimura and Kishimoto, 2010). Both transcription factors will precisely inhibit the formation of FoxP3 transcription factor so that the process of differentiation of naive $T$ cells into Treg cells will be inhibited. Both transcription factors also cause transcription of IL-17 cytokine which is the marker of Th17 cells. The formation of Th17 cells due to the production of IL-6 cytokines in SLE will stimulate the more severe inflammatory process. It is said that the balance between Treg and Th17 is important in the pathogenesis of chronic SLE (Ma et al., 2010; Yang et al.,
2011). Increased activity of Th17 and decreased Treg activity due to IL-6 were positively correlated with severity in SLE patients (Shah et al., 2010). Therefore, agents who can restore the balance of Th17 and Treg roles are potential targets for improving SLE symptoms (Guimaraes et al., 2017). The results showed that doses of third dose of EDI dsDNA $(1 \mu \mathrm{g} / \mathrm{ml}$, $10 \mu \mathrm{g} / \mathrm{ml}, 100 \mu \mathrm{g} / \mathrm{ml}$ ) decreased Th17/Treg cell ratio compared with positive control group. The decrease of Th17/T-reg cell ratio at that dose did not differ significantly with the negative control group (healthy mice). Thus, EDI administration of dsDNA has the potential to restore the balance of Th17 cell numbers with T-reg cells.

Th17 cells are a subset of CD $4+T$ cells that can produce IL-17 cytokines. Th17 was found to infiltrate the renal patients with lupus nephritis and skin tissue lesions in SLE patients (Crispin et al., 2008) CD4 CD8 T-cells may be a source of IL17 expression in SLE (Apostolidis et al., 2011) These double negative $\mathrm{T}$ cells were found to develop in SLE patients and were also found in experimental animals. It contributes to the loss of immune tolerance (Crispin and Tsokos, 2009) because it expresses IL-1 $\beta$ and IFN $\gamma$, and promotes cell differentiation $\mathrm{B}$ and autoantibody production (Tsokos et al., 2016) Increased IL-17 cytokines in SLE can be suppressed by the production of TGF- $\beta$ cytokines by T-reg cells. The balance of IL-17 as Th17 cytokine with TGF- $\beta$ as T-reg cytokine is needed to prevent tissue damage. In this study, EDI therapy dsDNA may reduce the ratio of IL-17/TGF- $\beta$ cytokines to the optimal dose obtained at the $3 \mathrm{rd}$ dose of therapy $(1 \mu \mathrm{g} / \mathrm{ml}, 10$ $\mu \mathrm{g} / \mathrm{ml}, 100 \mu \mathrm{g} / \mathrm{ml})$. 
The study by alkahoshi et al31, analyzed ratio Th1:Th2 on peripheral blood cells of SLE patients compared with normal control. Detection of intracellular cytokines was performed by flowcytometry method used to determine Th1 cells and Th2 cells. Patients with SLE with chronic proteinuria had an elevated percentage of peripheral Th1 cells compared with healthy controls. The Th /Th2 balance of SLE patients with grade IV Nephritis shows a shift to Th1 (Akahoshi et al., 1999). This data supports the theory that exacerbations of nephritis in SLE are mediated by Th1 cytokines such as IFN $\gamma$. It has been shown that IFN $\gamma$ becomes a cytokine that plays an important role in the development of autoimmune disease in the kidney (Schwarting et al., 1998).

In SLE patients, B-cell hyperactivity is associated with the production of Th2 cytokines that lead to excessive autoantibody production. However, the role of Th1 cytokine is also equally known. Both Th1 and Th2 cytokines can play a role in supporting or inhibiting autoimmune disease. In the study of Sayed et al., IFN $\gamma$ showed a negative correlation with Th2 cytokines (IL4 and IL10) (El-Sayed et al., 2008). Recent studies have shown that cytokine levels change in SLE. The high proinflammatory cytokines may precipitate exacerbations of the inflammatory response, apoptosis and autoantibody production that initiate and maintain disease activity (Yap and Lai, 2010; Postal et al., 2013). It is commonly agreed that there is a predominance of Th2 response involvement or Th1 and Th2 responses leading to an autoimmune SLE (Dolff et al., 2011; Theofilopoulos et al., 2013; Miyake et al., 2011). SLE and disease activity were characterized by Th1, Th17 and Treg profiles along with a decrease in IL-4 production. Serum cytokine levels and profiles in SLE are slightly modulated by vitamin D, BMI and TNF $\beta$ Ncol polymorphism status, primarily by the TNFB1 / B1 genotype. These three factors can aggravate Th1 and Th17 and IL-6 responses to SLE. Elevated Th1 is coupled with an increased in Th17 but decreases Th2 activity and elevated levels of IL-10 could be the target of new drugs in SLE. These results suggest that cytokine modulation strategies have the potency for treatment of SLE as well as profiles of Th1, Th17, and Treg along with decreased IL-4 production can be promised as disease activity biomarkers (Guimaraes et al., 2017). This correlated with the results of the study that administering EDI dsDNA at the third dose $(1 \mu \mathrm{g} / \mathrm{ml}, 10 \mu \mathrm{g} / \mathrm{ml}, 100 \mu \mathrm{g} / \mathrm{ml})$ could significantly lower Th1 / Th2 cell ratio compared to the positive control group. The decrease in Th1/Th2 cell ratio did not differ significantly with the negative control group indicating the EDI dsDNA therapy can restore the balance of Th1 and Th 2 cells. This balance can prevent exacerbations and tissue damage on SLE.

The results showed that third dose of EDI dsDNA $(1 \mu \mathrm{g} / \mathrm{ml}, 10 \mu \mathrm{g} / \mathrm{ml}, 100 \mu \mathrm{g} / \mathrm{ml})$ was able to significantly lower Th1/Th2 cell, Th17/Treg cell, and significant IL-17/TGF- $\beta$ compared with the positive control group. This process is mediated by Treg cell activation through increased TGF- $\beta$ cytokines due to the escalating dose of dsDNA therapy. Treg cells have a suppressive function of the inflammatory response by producing TGF- $\beta$ cytokines which is proven to reduce the activity of other immune 
cells. Previous research has also shown that

Treg cells play a direct role in inhibiting the activity of Th1, Th2, and Th17 Xu et al., 2003).

\section{CONCLUSION}

Desensitization of self-antigen dsDNA especially with dose III $(1 \mu \mathrm{g} / \mathrm{ml}, 10 \mu \mathrm{g} / \mathrm{ml}, 100$ $\mu \mathrm{g} / \mathrm{ml}$ ) is an effective dose in regulating the

\section{REFERENCES}

Afzali B, Lombardi G, Lechler R I and Lord G M 2007 The role of $\mathrm{T}$ helper 17 (Th17) and regulatory $\mathrm{T}$ cells (Treg) in human organ transplantation and autoimmune disease $J$ Clin Exp Immunol. 148 32-46.

Akahoshi M et al 1999 Th1/Th2 balance of peripheral $\mathrm{T}$ helper cells in systemic lupus erythematosus. Arthritis Rheum. 42 1644-8.

Anderson P O, Manzo B A, Sundstedt A, Minaee S, Symonds A, Khalid S, Rodriguez-Cabezas M E, Nicolson K, Li S, Wraith D C and Wang P 2006 Persistent antigenic stimulation alters the transcription program in $\mathrm{T}$ cells, resulting in antigen-specific tolerance Eur J Immunol. 36 1374-85.

Apostolidis S A, Crispín J C and Tsokos G C 2011 IL-17-producing T cells in lupus nephritis. Lupus. 20 120-4.

Burton BR, Britton GJ, Fang H, Verhagen J, Smithers B, Sabatos-Peyton C A, Carney L J, Gough J, Strobel S, Wraith D C 2014 Sequential transcriptional changes dictate safe balance of inflammatory cells in a pristaneinduced lupus mice model that can improve the tolerance of immune system.

and effective antigen-specific immunotherapy Nat Commun. 54741 Campbell J D, Buckland K F, McMillan S J, Kearley J, Oldfield W L G, Stern LJ, Grönlund H, van Hage M, Reynolds C J, Boyton R J and Cobbold S P 2009 Peptide immunotherapy in allergic asthma generates IL-10-dependent immunological tolerance associated with linked epitope suppression $J$ Exp Med.206 1535-47.

Choi J, Kim S T and Craft J 2012 The pathogenesis of systemic lupus erythematosus-an update. Curr Opin Immunol. 24 651-7.

Crispin J C and Tsokos G C 2009 Human TCR- + CD4- CD8- T cells can derive from $\mathrm{CD} 8+\mathrm{T}$ cells and display an inflammatory effector phenotype $J$ Immunol. 183 4675-81.

Crispín J C, Oukka M, Bayliss G, Cohen R A, Van Beek C A, Stillman I E, Kyttaris V C, Juang Y T and Tsokos G C 2008 Expanded double negative $\mathrm{T}$ cells in patients with systemic lupus erythematosus produce IL-17 and 
infiltrate the kidneys $J$ Immunol. 181 8761-6.

Dolff S, Bijl M, Huitema M G, Limburg P C, Kallenberg C G M and Abdulahad W H 2011 Disturbed Th1, Th2, Th17 and Treg balance in patients with systemic lupus erythematosus Clin Immunol. 141 197-204.

El-Sayed M, Nofal E, Mokadem S Al, Makhzangy I Al, Gaballah H and Akl H 2008 Correlative study of serum Th1/Th2 cytokines levels in patients with systemic lupus erythematosus with SLEDAI. Egypt Dermatol Online J. 4

Elias K M, Laurence A, Davidson T S, Stephens G, Kanno Y, Shevach E M and O'Shea J J 2008 Retinoic acid inhibits Th17 polarization and enhances FoxP3 expression through a Stat-3/Stat-5 independent signaling pathway Blood. 111 1013-20.

Fousteri G, Dave A, Bot A, Juntti T, Omid S and Von Herrath M 2010 Subcutaneous insulin B:9-23/IFA immunisation induces Tregs that control late-stage prediabetes in NOD mice through IL-10 and IFN $\gamma$ Diabetologia. 53 1958-70.

Gabrysová L, Nicolson KS, Streeter HB, Verhagen J, Sabatos-Peyton CA, Morgan DJ and Wraith D J 2009 Negative feedback control of the autoimmune response through antigen-induced differentiation of IL10-secreting Th1 cells J Exp Med. 206 1755-67.
Guimarães P M et al. 2017 Cytokines in systemic lupus erythematosus: Far beyond Th1/Th2 dualism lupus: Cytokine profiles. Immunol Cell Biol. 95 824-31.

Handono K, Marisa D and Kalim H 2013 Association between the low levels of vitamin $\mathrm{D}$ and Treg function in systemic lupus erythematosus patients. Acta Med Indones. 45 26-31.

Huang L et al 2012 Engineering DNA Nanoparticles as Immunomodulatory Reagents that Activate Regulatory $\mathrm{T}$ Cells J Immunol. 188 4913-20.

Kimura A and Kishimoto T 2010 IL-6: Regulator of Treg/Th17 balance Eur J Immunol. 40 1830-5.

Larché M and Wraith D C 2005 Peptide-based therapeutic vaccines for allergic and autoimmune diseases Nat Med. 11 S69

Ma J, Yu J, Tao X, Cai L, Wang J and Zheng S G 2010 The imbalance between regulatory and IL-17-secreting CD4+ $\mathrm{T}$ cells in lupus patients Clin Rheumatol. 29 1251-8.

Miyake K, Akahoshi M and Nakashima H 2011 Th subset balance in lupus nephritis. $\mathbf{J}$ Biomed Biotechnol 2011.

Pathak S and Mohan C 2011 Cellular and molecular pathogenesis of systemic lupus erythematosus: lessons from animal models. Arthritis Res Ther. 13 241.

Plantinga M et al 2011 Conventional and monocyte-derived CD11b+ dendritic cells initiate and maintain $\mathrm{T}$ helper 2 
cell-mediated immunity to house dust mite allergen Immunity 38 322-35.

Pusdatin Kementerian Kesehatan 2017 Situasi Lupus di Indonesia (Infodatin Jakarta) ISSN: 2442-7569

Postal M, Peliçari K O, Sinicato N A, Marini R, Costallat L T L and Appenzeller S 2013 Th1/Th2 cytokine profile in childhood-onset systemic lupus erythematosus. Cytokine. 61 785-91.

Sawla P, Hossain A, Hahn B H, Singh R P 2012 Regulatory $\mathrm{T}$ cells in systemic lupus erythematosus (SLE); Role of peptide tolerance Autoimmun Rev. 11 611-4.

Schwarting A, Wada T, Kinoshita K, Tesch G and Kelley V R 1998 IFN-gamma receptor signaling is essential for the initiation, acceleration, and destruction of autoimmune kidney disease in MRL-Fas(lpr) mice $J$ Immunol. 161 494-503.

Shah K, Lee W W, Lee S H, Kim SH, Kang SW, Craft J and Kang I 2010 Dysregulated balance of Th17 and Th1 cells in systemic lupus erythematosus Arthritis Res Ther. 12 R53.

Singh-Jasuja H, Thiolat A, Ribon M, Boissier MC, Bessis N, Rammensee HG and Decker P 2013 The mouse dendritic cell marker CD11c is down-regulated upon cell activation through Toll-like receptor triggering Immunobiology $21828-39$

Tarzi M, Klunker S, Texier C, Verhoef A, Stapel S O, Akdis C A, Maillere B, Kay A B and Larche M 2006 Induction of interleukin-10 and suppressor of cytokine signalling-3 gene expression following peptide immunotherapy. Clin Exp Allergy 36 465-74.

Theofilopoulos A N, Koundouris S, Kono D H and Lawson B R 2001 The role of IFN-gamma in systemic lupus erythematosus: a challenge to the Th1/Th2 paradigm in autoimmunity. Arthritis Res. 3 136-41.

Tsokos G C, Lo M S, Reis P C and Sullivan K E 2016 New insights into the immunopathogenesis of systemic lupus erythematosus Nat Rev Rheumatol. 12. 716

Wichainun R, Kasitanon N, Wangkaew S, Hongsongkiat S, Sukitawut W and Louthrenoo W 2013 Sensitivity and specificity of ANA and anti-dsDNA in the diagnosis of systemic lupus erythematosus: A comparison using control sera obtained from healthy individuals and patients with multiple medical problems. Asian Pac $J$ Allergy Immunol. 31 292-8.

Xu D, Liu H, Komai-Koma M, Campbell C, McSharry C, Alexander J and Liew F Y 2003 CD4+CD25+ regulatory $\mathrm{T}$ cells suppress differentiation and functions of Th1 and Th2 cells, leishmania major infection, and colitis in mice J Immunol 170 394-9.

Yang J, Yang X, Zou H, Chu Y and Li M 2011 Recovery of the immune balance between Th17 and regulatory $\mathrm{T}$ cells as a treatment for systemic lupus erythematosus Rheumatology (Oxford) 50 1366-72. 
Yap D Y H and Lai K N 2010 Cytokines and their roles in the pathogenesis of systemic lupus erythematosus: From basics to recent advances. $J$ Biomed Biotechnol. 2010.

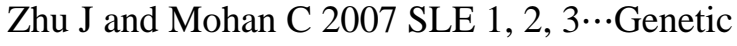
dissection of lupus. In: Immune Mediated Disease - From Theory to Therapy (Springer-New York)

\section{ACKNOWLEDGEMENT}

We thank Wahyudha, S.Si at Biomedic Laboratory, Brawijaya University for guiding us on flow cytometry analysis at the laboratory. This study was supported by Brawijaya University and funded by Directorate General of Higher Education (DGHE), Ministry of Research, and Indonesia. 